\title{
Granulomatous disease in the vermiform appendix
}

\author{
DC ALLEN, JD BIGGART
}

From the Histopathology Laboratory, The Laboratories, Belfast City Hospital, Belfast

SUMMARY In a twenty-year period 19 appendicectomy specimens were diagnosed as primary Crohn's disease. This represents $4.9 \%$ of the total number of both resection specimens and mucosal biopsies diagnosed as Crohn's disease during that time. This is a review of the main histopathological features found in these appendices and their subsequent clinical outcome. The predominant feature is transmural inflammation characterised by fibrosis and giant cell epithelioid granulomata. An accompanying spectrum of acute imflammatory changes is also seen. One patient progressed to more widespread ileal and caecal disease 17 months later. One patient developed perianal fistulae and chronic non-specific proctitis 24 months later. This represents a proven recurrence of one case in a study population of 19. The conclusion is that primary Crohn's disease of the appendix is usually an isolated phenomenon but rarely it may forewarn of more widespread bowel disease in the future. A discussion regarding the differential diagnosis of granulomatous appendiceal lesions is included.

Working from the Mount Sinai Hospital in New York, Crohn, Ginzburg and Oppenheimer in 1932," produced their classic report describing "a disease of the terminal ileum, affecting mainly young adults, characterised by a subacute or chronic necrotising and cicatrising inflammation". They emphasised involvement of the terminal ileum alone and stated that "the process never transcends the limits of Bauhin's valve, and that the appendix is always free from guilt and free from changes." Warren and Sommers in $1948,{ }^{2}$ quoted in reference Läwen's 1914 case of "appendicitis fibroplastica" which the author later recognised as a variation of cicatrising enteritis, and, they noted in their own study the widespread nature of the disease. This included colonic lesions, and appendiceal involvement in $24 \%$ of cases. Since that time it has been accepted that Crohn's disease may occur anywhere from the mouth to the anus and extraintestinal symptoms have been well established.

Meyerding and Bertram (1953), ${ }^{3}$ reported the first case of Crohn's disease confined to the appendix. This was followed by similar sporadic reports in the literature over the years. ${ }^{4-12} \mathrm{Hall}$ and Hellier ${ }^{5}$ noted that the appendiceal lesion may forewarn of future more widespread gut involvement.

This is a histopathological study of 19 cases of primary Crohn's disease of the vermiform appendix and their clinical outcome.

Accepted for publication 6 January 1983

\section{Material and methods}

Nineteen cases of primary Crohn's disease of the appendix have been reported by the Belfast City Hospital histopathology laboratory in the twentyyear period 1962-1982. This represents $4.9 \%$ of the total number of both resection specimens and mucosal biopsies diagnosed as Crohn's disease during that time. Patients with appendiceal involvement secondary to primary Crohn's disease elsewhere in the intestine have been excluded and used for histopathological comparison only. Also excluded were two cases resembling yersinial infection and one case in which the patient developed apical pulmonary tuberculosis some two years later.

An average of five transverse blocks were taken from each appendix, fixed in formalin, routinely processed and embedded in paraffin wax. Sections of 5-6 $\mu \mathrm{m}$ thick were produced and stained with haematoxylin and eosin, by the Ziehl-Neelson method and with Gomori's methenamine silver. These techniques were used to exclude tubercle bacilli, parasites, fungi and faecal material as causes of the granulomatous inflammation. Selective cases were Gram-stained to demonstrate Actinomyces filaments in the appendiceal lumen. In no case were mesenteric lymph nodes submitted.

The patients were followed clinically by means of their medical records for periods of up to three years. In three cases follow-up clinical data were not 
available and in another three further related specimens were available for examination.

\section{Results}

\section{CLINICAL DATA}

This review revealed 19 cases of Crohn's disease initially limited to the appendix representing $4.9 \%$ of the total Crohn's disease specimens diagnosed during that time. There were 11 males and eight females. The age range varied from 9-67 yr with an overall mean age of $24.4 \mathrm{yr}$. The male mean age was $20.5 \mathrm{yr}$, the female $29.8 \mathrm{yr}$. Four cases occurred in the period 1962-1975. Fifteen cases (79\%) occurred between the years 1976-1982.

Symptoms and operative findings are summarised in Table 1.

In five cases $(26.3 \%)$ there was a history of episodic lower abdominal pain ranging from three weeks to four years in duration. Notably two of these patients with a prolonged clinical history developed significant post-appendicectomy disease and another had an appendix abscess necessitating repeated admissions. The fourth and fifth patients had disease isolated to the appendix. The remaining 14 patients $(73.7 \%)$ had a short history of $\leqslant 72 \mathrm{~h}$ and a clinical diagnosis of acute appendicitis. Operative findings invariably showed an enlarged, inflamed appendix. Two appendices were adherent to the terminal ileum and two to the caecal pouch. In four cases the terminal ileum and caecum were oedematous and two cases had grossly identifiable appendix abscesses. Enlarged mesenteric lymph nodes were commented upon in one instance. By nature of the cases selected for the study, surgical specimens consisted of resected appendices alone following a diagnosis of acute appendicitis and not those on which a more widespread resection was performed, Crohn's disease having been recognised at the time of operation.

Table 1 Symptoms, operative findings and clinical outcome in 19 cases of Crohn's disease.

\begin{tabular}{|c|c|c|c|c|c|c|}
\hline \multirow{2}{*}{ No } & \multirow{2}{*}{ Patients } & \multicolumn{2}{|c|}{ Age (yr)/Sex } & \multirow{2}{*}{$\begin{array}{l}\text { Symptoms } \\
\text { 24h RIF pain }\end{array}$} & \multirow{2}{*}{$\begin{array}{l}\text { Operative findings } \\
\text { Enlarged, inflamed appendix }\end{array}$} & \multirow{2}{*}{$\begin{array}{l}\text { Clinical outcome } \\
\text { Negative Ba Meal FT at } 3 \text { months } \\
\text { Asymptomatic at } 6 \text { months }\end{array}$} \\
\hline & & 14 & $\mathbf{M}$ & & & \\
\hline 2 & $65-9474$ & 67 & $\mathbf{F}$ & 48h RIF pain & $\begin{array}{l}\text { Thickened appendix adherent to } \\
\text { oedematous caecal pouch }\end{array}$ & $\begin{array}{l}\text { Negative Ba Meal FT and } \\
\text { asymptomatic at } 3 \text { months }\end{array}$ \\
\hline 3 & $71-16938$ & 13 & $\mathbf{M}$ & No further clinical data & available & \\
\hline 4 & $73-1061$ & 31 & $\mathbf{F}$ & $\begin{array}{l}18 \text { months crampy } \\
\text { hypogastric pain. } \\
24 \mathrm{~h} \text { RIF pain }\end{array}$ & Enlarged, inflamed appendix & Asymptomatic at 24 months \\
\hline 5 & $76-8660$ & 18 & $\mathbf{F}$ & $24 \mathrm{~h}$ RIF pain & Congested appendix & Asymptomatic at 12 months \\
\hline 6 & $76-9870$ & 32 & $\mathbf{M}$ & $12 \mathrm{~h}$ RIF pain & $\begin{array}{l}\text { Thickened, inflamed perforated } \\
\text { appendix: small bowel mesentery } \\
\text { oedematous, gland enlargement }\end{array}$ & $\begin{array}{l}\text { Ba meal FT showed restricted } \\
\text { filling due to ileal scarring } \\
\text { Asymptomatic at } 6 \text { months }\end{array}$ \\
\hline $\begin{array}{l}7 \\
8\end{array}$ & $\begin{array}{l}76-10383 \\
76-10401\end{array}$ & $\begin{array}{l}16 \\
20\end{array}$ & $\begin{array}{l}M \\
M\end{array}$ & $\begin{array}{l}\text { No further clinical data } \\
\text { No further clinical data }\end{array}$ & $\begin{array}{l}\text { available } \\
\text { available }\end{array}$ & \\
\hline 9 & $76-14114$ & 17 & $\mathbf{M}$ & $24 \mathrm{~h}$ RIF pain & $\begin{array}{l}\text { Enlarged, inflamed appendix } \\
\text { adherent to caecal base }\end{array}$ & $\begin{array}{l}\text { Negative Ba Meal FT at } 3 \text { months } \\
\text { Asymptomatic at } 8 \text { months }\end{array}$ \\
\hline 10 & $76-24879$ & 19 & $\mathbf{M}$ & $\begin{array}{l}\text { 24h RIF pain with } \\
\text { slight diarrhoea }\end{array}$ & $\begin{array}{l}\text { Enlarged, inflamed appendix } \\
\text { buried in an appendix mass }\end{array}$ & Asymptomatic at 24 months \\
\hline 11 & $77-10146$ & 24 & $\mathbf{M}$ & $72 \mathrm{~h}$ RIF pain & $\begin{array}{l}\text { Enlarged, inflamed appendix } \\
\text { Oedematous caecum and small bowel }\end{array}$ & $\begin{array}{l}\text { Negative Ba Meal FT at } 2 \text { months } \\
\text { Asymptomatic at } 24 \text { months }\end{array}$ \\
\hline 12 & $78-9073$ & 31 & $\mathbf{M}$ & $\begin{array}{l}8 \text { months RIF pain } \\
2 \text { previous admissions } \\
\text { for an appendix mass }\end{array}$ & Enlarged, congested appendix & $\begin{array}{l}\text { Ba Meal FT did not outline the ileum } \\
\text { Asymptomatic at } 24 \text { months }\end{array}$ \\
\hline 13 & $78-15079$ & 9 & $\mathrm{~F}$ & $24 \mathrm{~h}$ RIF pain & $\begin{array}{l}\text { Inflamed appendix. Lower half } \\
\text { surrounded by omentum and } \\
\text { abscess formation }\end{array}$ & Asymptomatic at 6 months \\
\hline 14 & $78-24107$ & 22 & $\mathrm{~F}$ & $\begin{array}{l}2 \text { months lower } \\
\text { abdominal pain }\end{array}$ & Enlarged, oedematous appendix & $\begin{array}{l}\text { Negative rectal mucosal biopsy at } \\
3 \text { months }(79-2821) \\
\text { Asymptomatic at } 36 \text { months }\end{array}$ \\
\hline 15 & $79-1328$ & 33 & $\mathbf{F}$ & 24h RIF pain & Not available & Asymptomatic at 2 months \\
\hline 16 & $79-16611$ & 36 & $\mathbf{F}$ & $\begin{array}{l}48 \text { months lower } \\
\text { abdominal cramps } \\
\text { with diarrhoea }\end{array}$ & $\begin{array}{l}\text { Inflamed appendix } \\
\text { Small bowel normal }\end{array}$ & $\begin{array}{l}\text { Over the next } 24 \text { months developed } \\
\text { (i) perianal fistulae } \\
\text { (ii) chronic non-specific proctitis } \\
\text { proven by rectal biopsy }(80 / 11141)\end{array}$ \\
\hline 17 & $79-18823$ & 20 & M & Clinical data not availab & & Asymptomatic at 24 months \\
\hline 18 & 8()$-4474$ & 20 & $\mathbf{M}$ & $\begin{array}{l}\text { Three weeks crampy } \\
\text { abdominal pain } \\
24 \text { h RIF pain }\end{array}$ & $\begin{array}{l}\text { Thickened appendix adherent to } \\
\text { an oedematous terminal ileum }\end{array}$ & $\begin{array}{l}\text { Ba Meal FT showed oedema and ileitis } \\
\text { suggestive of Crohn's disease } \\
17 \text { months later underwent resection of } \\
\text { terminal ileum, caecum and ascending } \\
\text { colon for Crohn's disease ( } 81 / 18282)\end{array}$ \\
\hline 19 & $81-8731$ & 22 & $\mathbf{F}$ & Not available & $\begin{array}{l}\text { Inflamed appendix adherent to } \\
\text { small bowel }\end{array}$ & Asymptomatic at 6 months \\
\hline
\end{tabular}




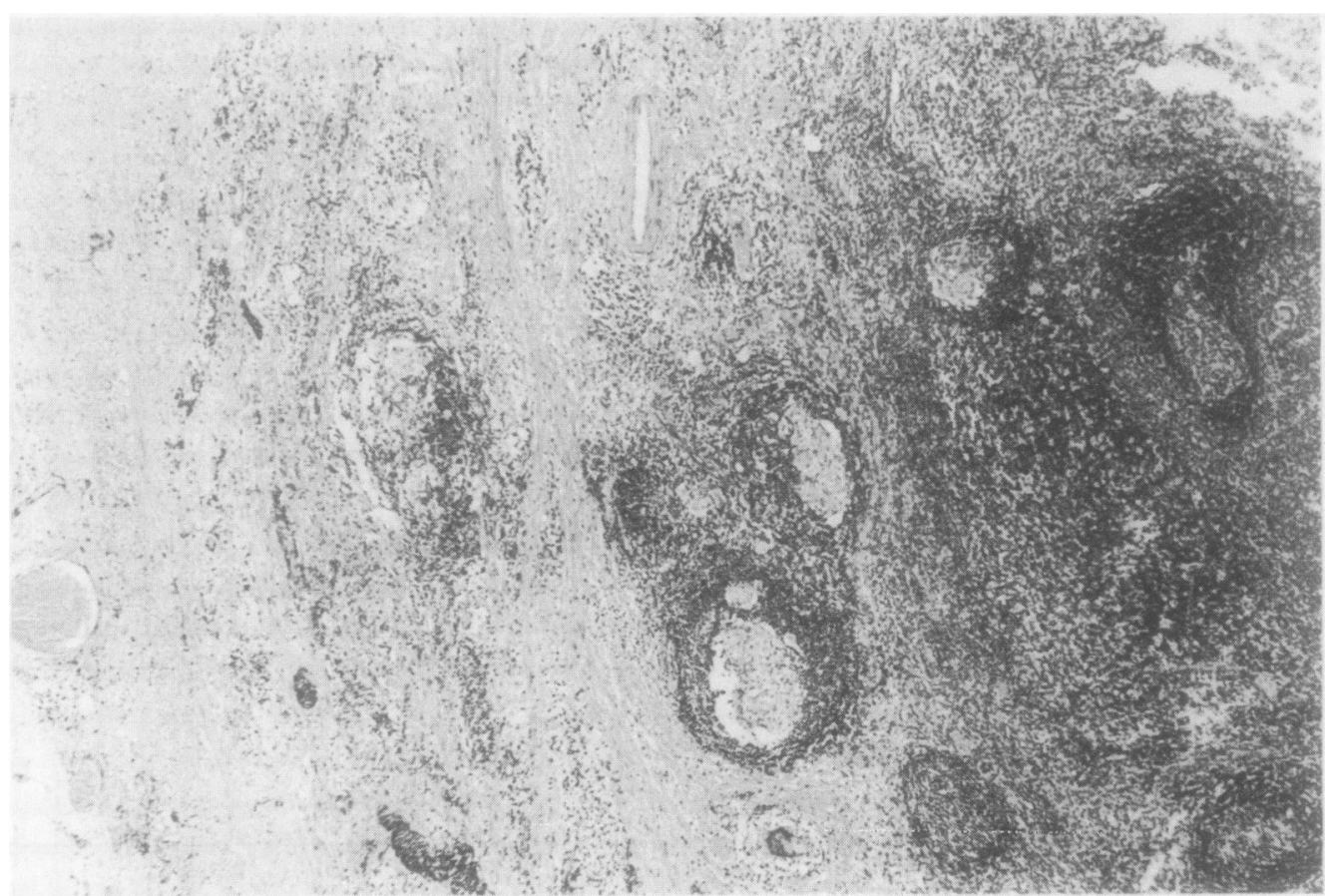

Fig. 1 Chronic transmural inflammation. There is epithelial ulceration and giant cell epithelioid granulomata in the submucosal lymphoid aggregates and the thickened, partially fibrosed muscle coat. Note the association of lymphoid aggregates, even, in the thickened serosa (left). Haematoxylin and eosin $\times 50$.

Table 2 Histological findings in 19 cases of Crohn's disease

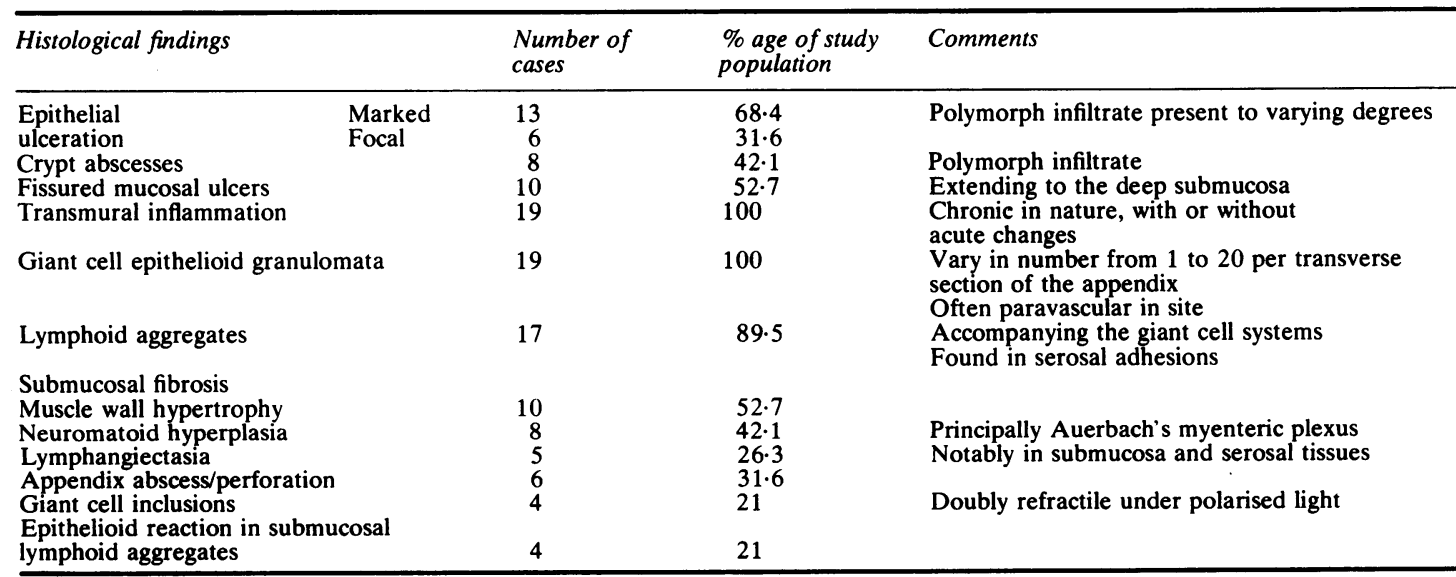

\section{PATHOLOGY}

The majority of the appendices were enlarged and firm on external examination, the mean diameter after tissue processing being $10.7 \mathrm{~mm}$. Allowing $15 \%$ shrinkage the mean diameter is estimated at $12.6 \mathrm{~mm}$. Two cases were $2 \mathrm{~cm}$ in diameter. Two appendix abscesses were identified macroscopically $\frac{70}{0}$ Serosal thickening and congestion of the appendix were a constant finding.

Histological examination revealed the features listed in Table 2.

The main findings were chronic transmurap 


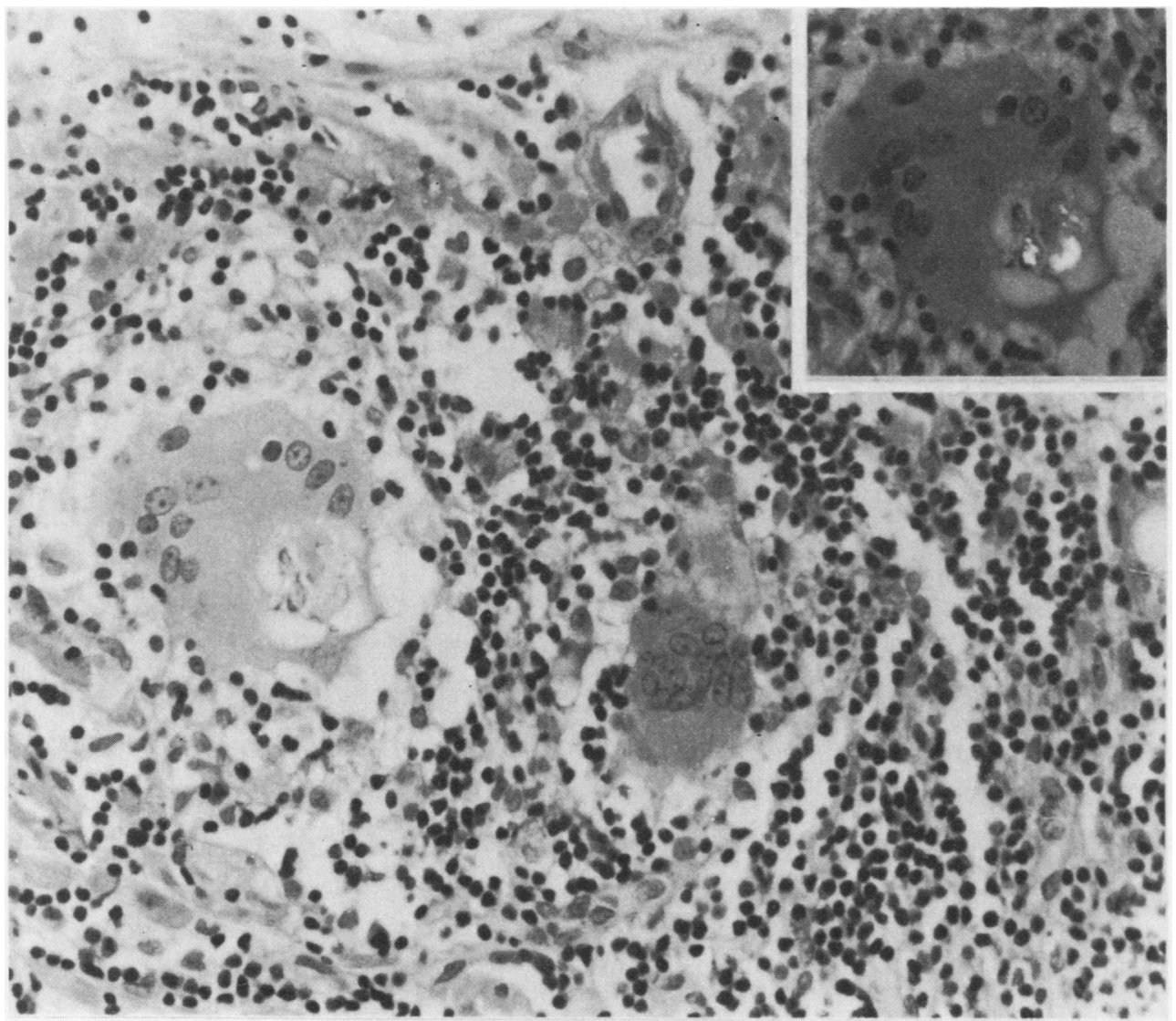

Fig. 2 Giant cell granulomata with central giant cells set in an epithelioid and lymphocyte infiltrate. Note the Schaumann body type of cytoplasmic inclusions. Inset: Inclusion seen by polarised light. Haematoxylin and eosin $\times 400$.

inflammation. This consisted of oedema, submucosal fibrosis and muscle coat hypertrophy (52.7\% of cases) but in addition all cases revealed giant cell epithelioid granulomata of the sarcoid type (Fig. 1).

The granulomata varied in number from 1-20 per transverse section, and also location. The deep submucosa and muscle coat serosa junction were particularly involved but giant cell systems were not uncommon in the mucosa, muscle coat and mesoappendix. Serosal and mesoappendiceal granulomata were often paravascular and paralymphatic in site. The granulomata consisted of one or two central giant cells set amongst epithelioid cells with a heavy surrounding rim of lymphocytes (Fig. 2).

The giant cells had up to 15 grouped nuclei and four $(21 \%)$ contained Schaumann-like cytoplasmic inclusions which were doubly refractile under polarised light (Fig. 2 [insert]).

Marked lymphoid aggregates were present in the thickened serosa and accompanying the giant cell systems in $17(89.5 \%)$ of cases (Fig. 1).

Acute inflammatory changes were seen in all cases, there was marked epithelial ulceration and a transmural infiltrate in $13(68.4 \%)$ of patients. Focal ulceration occurred in six cases. Crypt abscess formation and fissured mucosal ulcers were found in eight and 10 cases respectively (Figs. 3 and 4). Perforation with resultant abscess complicated six cases.

Other associated findings included neuromatoid hyperplasia of Auerbach's myenteric plexus $(42.1 \%)$, lymphangiectasia $(26.3 \%)$ and an epithelioid reaction in the submucosal lymphoid aggregates $(21 \%)$. It must be emphasised that no caseous necrosis was seen in the granulomata. One case showed minimal central fibrinoid necrosis with sparse accompanying polymorphs. Ziehl-Neelson stains were negative. Vegetable matter was found in the lumen only of one appendix, Actinomyces colonies in two: the Gram-positive filaments were 


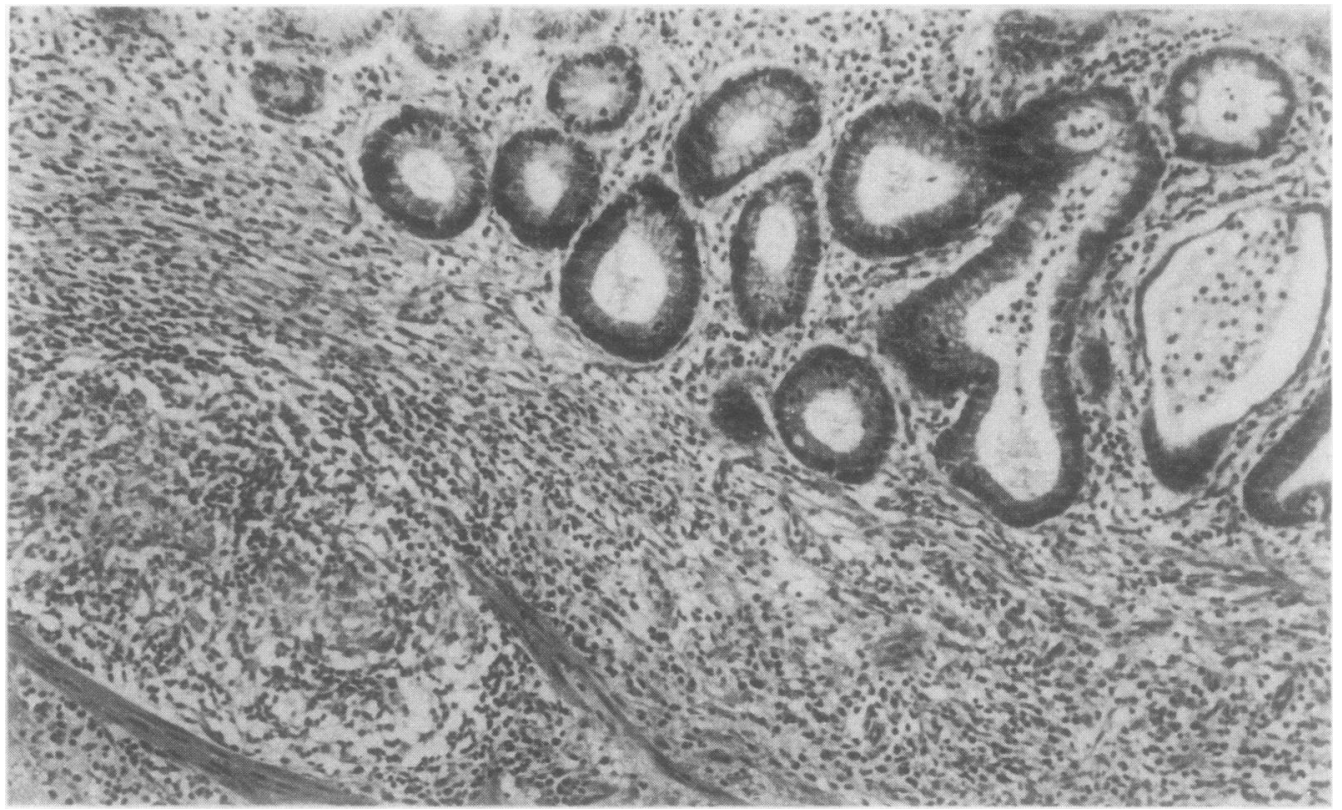

Fig. 3 Incipient crypt abscess formation with dilated glands containing polymorphs. There is a small mucosal sarcoid like granuloma alongside. Haematoxylin and eosin $\times 250$.

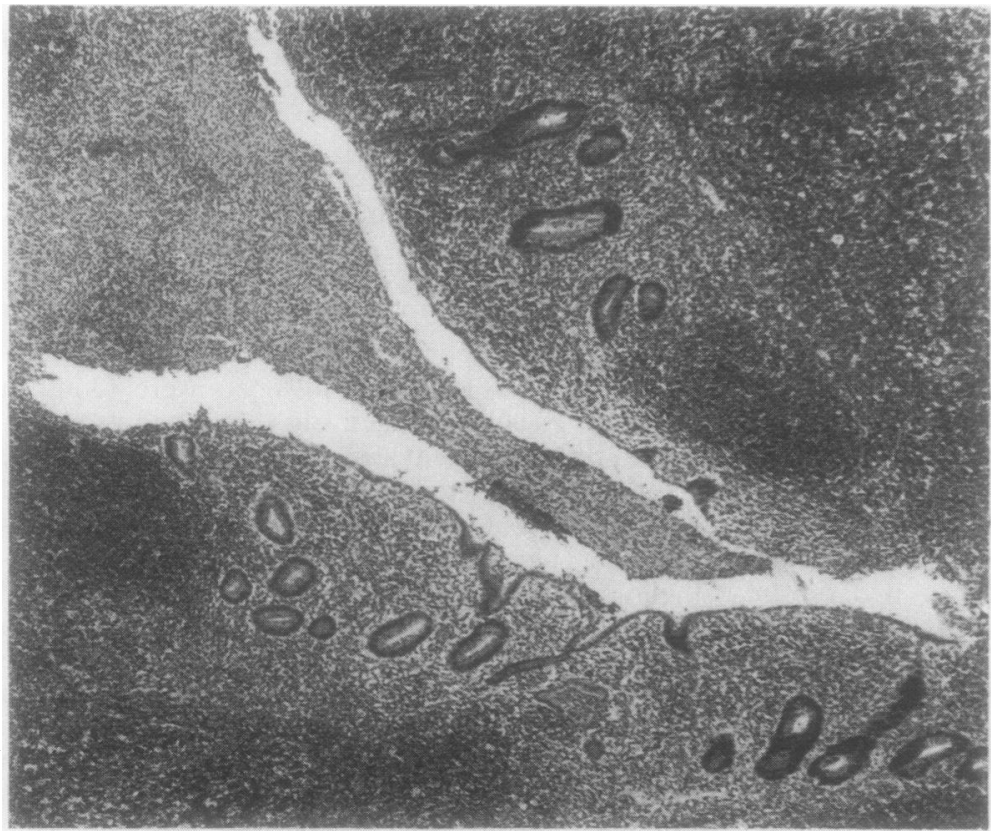

Fig. 4 A typical fissuring mucosal ulcer spreading into the submucosa. Haematoxylin and eosin $\times 50$. 
not demonstrable in the appendix wall. A careful search in each case failed to reveal foreign body material as a cause of the granulomatous reaction.

FOLLOW-UP (TABLE 1)

A twenty-year old man had a post-operative barium study showing a terminal ileitis suggestive of Crohn's disease. This oedematous terminal ileum had been noted at the time of operation and 17 months later after continued abdominal cramps and diarrhoea he underwent further surgery involving resection of his terminal ileum, caecum and ascending colon for confirmed Crohn's disease. One other patient, a thirty-six-year old woman, developed perianal fistulous disease over the next 24 months (not biopsied) and chronic diarrhoea which on rectal biopsy proved to be a chronic non-specific proctitis (granulomata were not seen). Fourteen patients remained asymptomatic for follow-up periods from three months to three years, six of whom had barium screening postoperatively. In two of these cases the ileum did not outline due to oedema and scarring. One patient was further investigated by a rectal mucosal biopsy three months post appendicectomy. This was normal. In three instances no follow-up information was available.

\section{Discussion}

The histological diagnosis of Crohn's disease rests largely on the finding of transmural inflammation with lymphoid aggregates and the presence of typical sarcoid type granulomata. The term sarcoid is used here in a histological sense as it embraces a number of conditions including tuberculosis, sarcoidosis, beryllium poisoning, foreign body reaction and various infective causes. ${ }^{13}$ Tuberculosis may be diagnosed by a combination of central caseous necrosis, and the demonstration of acid and alcohol fast bacilli. Histologically the granulomatous reaction is usually more confluent and less discrete than in Crohn's disease. The chest $x$-ray and Mantoux status are also helpful. Sarcoidosis of the appendix has been described but designated as such only when lung, liver, skin, bone and scleral involvement were also found.$^{14}$ The close histological similarity between sarcoidosis and Crohn's disease is borne out by Mitchell $e$ al $^{15}$ who noted a positive Kveim test in $50 \%$ of their study population who had Crohn's disease. It can be said, however, that a diagnosis of sarcoidosis confined to the gut is dubious. Foreign body reaction should reveal the offending material, usually vegetable matter from the faeces, and qualitatively different giant cell systems with centrally grouped nuclei and a lack of epithelioid reaction. ${ }^{16}$ A careful search should be made for doubly refrac- tile material under polarised light. Fungal hyphae will be demonstrated by silver impregnation stains and their intramural location is thought necessary to cause the granulomatous reaction. Parasitic infestation-for example schistosomiasis-is sought and excluded. Ewen et $\mathrm{ll}^{7}$ noted that in longstanding non-specific chronic inflammation of the appendix with abscess formation a transmural sarcoid reaction was not noted and at most there were a few sparse serosal granulomata. Acute appendicitis with perforation and chronic abscess formation is not therefore a cause of a transmural granulomatous inflammation. Diverticular disease both localised to the appendix and in adjacent bowel must be ruled out. A diagnosis of Crohn's disease may be made with relative confidence when granulomata fulfilling the above criteria are seen.

Since the first report of primary Crohn's disease of the appendix ${ }^{3}$ there have been similar but sporadic cases culminating in a series of 14 cases. $^{12}$ Meyerding's patient remained asymptomatic at one year and it was left to Hall and Hellier ${ }^{5}$ to note the possibility of disease recurrence with a rectal biopsy showing Crohn's granulomata three months post appendicectomy. Ewen et $\mathrm{al}^{7}$ reported three cases two of which developed further colonic Crohn's disease at periods of four months and four years. Yang et al $^{12}$ recorded disease recurrence in three of 14 cases and a close similarity in clinicopathological data to this Belfast City Hospital series.

In this present study of 19 cases of Crohn's disease initially limited to the appendix the male to female ratio was 11:8 and the mean age $24.4 \mathrm{yr}$. Nearly four times as many cases occurred from 1976-1982 as from 1962-1975. Five patients $(26.3 \%)$ had a clinical history longer than three weeks' duration. The clinical diagnosis in the majority of cases was acute appendicitis. Operative findings were non-specific showing enlarged, inflamed appendices and could not be consistently correlated with the diagnosis and eventual clinical outcome. A suspicion of Crohn's disease may be raised by features such as enlarged appendix diameter, oedematous small bowel and mesentery. No postoperative fistulae resulted. The thickened appendices showed chronic transmural inflammation with lymphoid aggregates and giant cell systems. Fissured mucosal ulcers were also prominent. Three cases were devoid of any further clinical data; only one patient $(5.3 \%)$ developed proven recurrent Crohn's disease over a 17 month period. Fourteen patients remained asymptomatic. One patient developed perianal fistulae and a chronic nonspecific proctitis.

In conclusion it is seen that Crohn's disease can occur isolated to the appendix and may precipitate 
an episode of acute appendicitis. Treatment is routine appendicectomy with close review. Postoperative fistula formation was not seen in this present series. The appendiceal lesion may rarely forewarn of further more widespread disease. Finally it is speculated that Crohn's disease in the appendix may form part of a spectrum of subclinical intestinal Crohn's lesions brought to attention at that time by a superimposed episode of acute appendicitis. Concurrent biopsies taken from other sites-for example, rectum, stomach, and lymph nodes-may be of use in predicting the extent and outcome of the disease. It has not been possible to assess this hypothesis in this short review study.

The authors are very grateful to Mr John Orchin BA, FIMLS, MI(Biol) for his photographic and technical expertise, Miss Jacqueline McLaren for secretarial assistance and finally our clinical colleagues throughout Northern Ireland without whom this study would not have been possible.

\section{References}

' Crohn BB, Ginzburg L, Oppenheimer GD. Regional ileitis: a pathologic and clincal entity. JAMA 1932;99:1323-9.

2 Warren S, Sommers SC. Cicatrising enteritis (regional ileitis) as a pathologic entity: analysis of one hundred and twenty cases. Am J Pathol 1948;24:475-501.

${ }^{3}$ Meyerding EV, Bertram HF. Non-specific granulomatous inflammation (Crohn's disease) of the appendix. Surgery 1953;34:891-4.
${ }^{4}$ Hollings RM. Crohn's disease of the appendix. Med J Aust 1964;1:639-41.

${ }^{5}$ Hall JH, Hellier MD. Crohn's disease of the appendix presenting as acute appendicitis. Br J Surg 1969;56:390-2.

- Ring AM. Isolated regional ileitis of the appendix. Int Surg 1970;54:290-4.

${ }^{7}$ Ewen SWB, Anderson J, Galloway JMD, Miller JDB, Kyle J. Crohn's disease initially confined to the appendix. Gastroenterology 1971;60:853-7.

${ }^{8}$ Hobson RW, Howard EW, Tuttle JR, Jenis EH. Crohn's disease of the appendix. Am Surg 1973;39:349-51.

- Geerken RG, Gibbons RB. Isolated Crohn's disease of the $\vec{\circ}$ appendix: case report. Milit Med 1974;139:215-7.

${ }^{10}$ Weiss Y, Durst AL. Crohn's disease of the appendix: presenta- $\vec{\omega}$ tion of a case with review of the literature. Am J Gastroenterol 1975;63:334-9.

"Green GI, Broadrick GL, Collins JL. Crohn's disease of the appendix presenting as acute appendicitis. Am J Gastroenterol 1976;65:74-7.

${ }^{12}$ Yang SS, Gibson P, McCaughey RS, Arcari FA, Bernstein J. Primary Crohn's disease of the appendix: report of 14 cases $\mathrm{N}$ and review of the literature. Ann Surg 1979;189/3:334-9.

${ }^{13}$ Morson BC, Dawson IMP. Gastrointestinal Pathology 2nd ed. Oxford: Blackwell, 1979.

${ }^{14}$ Macleod IB, Jenkins AM, Gill W. Sarcoidosis involving the vermiform appendix. J $R$ Coll Surg Edinb 1965;10:319-23.

is Mitchell DN, Cannon P, Dyer NH, Hinson KFW, Willoughby JMT. The Kveim test in Crohn's disease. Lancet 1969;2:571- $\vec{\bullet}$ 3.

${ }^{16}$ Lockhart-Mummery HE, Morson BC. Crohn's disease of the large intestine. Gut 1964;5:493-509.

Requests for reprints to: Dr DC Allen, Department of $\frac{\mathscr{Q}}{\mathbb{Q}}$ Histopathology, Belfast City Hospital, Belfast BT9 7AD, $\mathrm{N}$ Ireland. 